\title{
Utility of Maternal 6-Thioguanine Nucleotide Levels in Predicting Neonatal Pancytopenia
}

\author{
Hidehiko Maruyama, MD, PhD ${ }^{1}$ Katsuhiko Tada, MD, PhD ${ }^{2}$ Takuzo Fujiwara, MD, $\mathrm{PhD}^{3}$ \\ Kosuke Ota, MD, $\mathrm{PhD}^{4}$ Misao Kageyama, $\mathrm{MD}^{1}$
}
1 Department of Neonatology, National Hospital Organization, Okayama Medical Center, Okayama, Japan
2 Department of Obstetrics and Gynecology, National Hospital Organization, Okayama Medical Center, Okayama, Japan
3 Department of Surgery, National Hospital Organization, Okayama
Medical Center, Okayama, Japan
${ }^{4}$ Department of Nephrology, National Hospital Organization,
Okayama Medical Center, Okayama, Japan

Am J Perinatol Rep 2013;3:25-28.

\begin{abstract}
Address for correspondence Hidehiko Maruyama, MD, PhD, Department of Pediatrics, Kochi Health Sciences Center, 2125-1 Ike Kochi Kochi 781-8555, Japan (e-mail: maruyamahidehiko@gmail.com).
\end{abstract}

\author{
Abstract \\ Keywords \\ - azathioprine \\ - pancytopenia \\ - 6-thioguanine \\ nucleotides
}

An infant with pancytopenia was born to a mother who used the common immunosuppressant azathioprine (AZA). Maternal and neonatal blood levels of 6-thioguanine nucleotides (6TGN; metabolite of AZA) were 1890 and $1480 \mathrm{pmol} / 8 \times 10^{8}$ red blood cells, respectively. Maternal 6TGN levels could be useful in predicting neonatal pancytopenia.
Azathioprine (AZA), a common immunosuppressant, has been reported to cause bone marrow suppression in infants when used during pregnancy and breast-feeding. ${ }^{1,2}$ AZA is rapidly metabolized to cytotoxic 6-thioguanine nucleotides (6TGN). ${ }^{3}$ Thiopurine methyltransferase (TPMT) is an important enzyme for AZA metabolism. ${ }^{4}$ Genetic polymorphisms in TPMT are associated with decreased enzymatic activity. Moreover, these polymorphisms are associated with increased myelosuppression risk, ${ }^{5}$ as decreased TPMT activity leads to elevated 6TGN levels. ${ }^{6}$ Severe renal dysfunction has been reported to raise 6TGN levels by 8 - to $>10$-fold. ${ }^{7}$ Here we report a case in which an infant with pancytopenia was born to a mother who had used AZA during pregnancy and breast-feeding. Maternal and neonatal blood 6TGN levels were obtained with written informed consent from the mother.

\section{Case Report}

A boy was born to a 31-year-old primiparous woman with a history of renal transplantation at age 22 due to Goodpasture's syndrome. She had been well maintained on AZA, cyclosporine (CsA), methylprednisolone (mPSL), and benzbromarone. At pregnancy, dosages were: AZA $50 \mathrm{mg} / \mathrm{d}$, CsA $150 \mathrm{mg} / \mathrm{d}$, and $\mathrm{mPSL} 2 \mathrm{mg} / \mathrm{d}$ (maternal weight, $50 \mathrm{~kg}$ ). Benzbromarone was changed to probenecid. Laboratory test results at 7 weeks 1 day were: blood urea nitrogen (BUN) $19 \mathrm{mg} / \mathrm{dL}$, creatinine (Cre) $1.36 \mathrm{mg} / \mathrm{dL}$, and uric acid (UA) $3.7 \mathrm{mg} / \mathrm{dL}$ (- Fig. 1). At 18 weeks, lower-extremity edema and elevated serum Cre levels were noted. She was admitted to the hospital at 20 weeks 2 days. At that time, fetal anatomy and growth were normal. At 23 weeks 6 days, AZA dose was increased from 50 to $75 \mathrm{mg} / \mathrm{d}$, CsA dose was decreased from 150 to $80 \mathrm{mg} / \mathrm{d}$, and mPSL dose was intermittently increased to $24 \mathrm{mg} / \mathrm{d}$. Maternal blood test results at 33 weeks 2 days were: BUN $29 \mathrm{mg} / \mathrm{dL}$, Cre $2.4 \mathrm{mg} / \mathrm{dL}$, UA $7.2 \mathrm{mg} /$ $\mathrm{dL}$, white blood cells $7500 / \mu \mathrm{L}$, hemoglobin $8.2 \mathrm{~g} / \mathrm{dL}$, and platelets $215 \times 10^{3} / \mu \mathrm{L}$. Given the fetal growth arrest in a 2 week period, labor was induced at 34 weeks 0 days. The boy was born with a birth weight of $1810 \mathrm{~g}$, height of $39 \mathrm{~cm}$, head circumference of $31.2 \mathrm{~cm}$, chest circumference of $25.8 \mathrm{~cm}$, Apgar score of $8 / 9$, and no major anomaly. The boy had dyspnea and was diagnosed with transient tachypnea, received

May 24, 2012

accepted after revision

July 27, 2012

published online

December 3, 2012
Copyright $\odot 2013$ by Thieme Medical Publishers, Inc., 333 Seventh Avenue, New York, NY 10001, USA. Tel: +1(212) 584-4662.
DOI http://dx.doi.org/ 10.1055/s-0032-1329683. ISSN 2157-6998. 


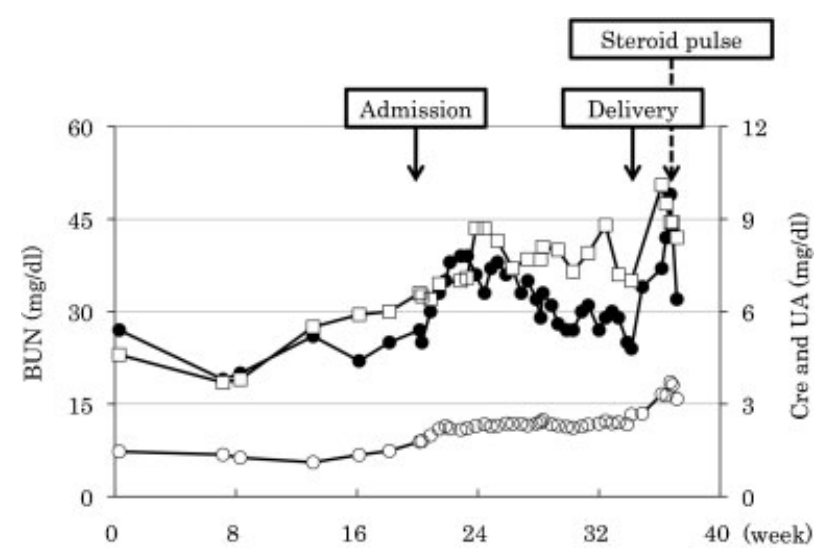

Fig. 1 Maternal blood urea nitrogen (BUN; filled circle), creatinine (Cre; open circle), and uric acid (UA; open square) during pregnancy are shown. These parameters gradually worsened despite changes in treatment. The mother was admitted to the hospital at 20 weeks 2 days. At 34 weeks 0 days, labor was induced. Steroid pulse therapy was performed from day 16 postdelivery.

requiring oxygen supplementation at day 1 and nasal directional positive airway pressure at day 3 .

Leukocytopenia, lymphocytopenia, and macrocytic hyperchromatic anemia were noted at birth ( - Table $\mathbf{1})$. There was no $\mathrm{ABO}$ incompatibility or fetomaternal transfusion. Maternal and neonatal blood levels of $6 \mathrm{TGN}$ were $1890 \mathrm{pmol} / 8 \times 10^{8}$ red blood cells (RBC) at day 2 and $1480 \mathrm{pmol} / 8 \times 10^{8} \mathrm{RBC}$ at day 3, respectively. Neonatal CsA level was $<30 \mathrm{ng} / \mathrm{mL}$ at day 3. Blood test results were negative for cytomegalovirus

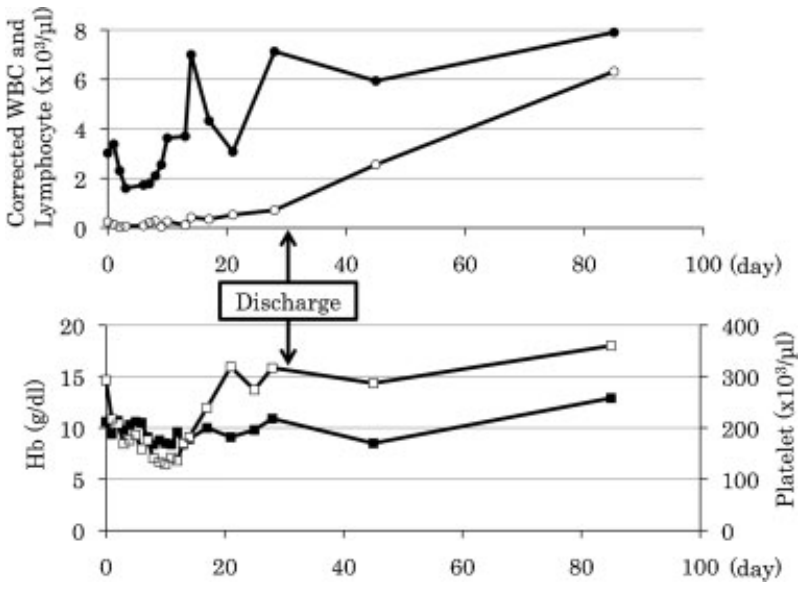

Fig. 2 Corrected white blood cells (WBC; filled circle), lymphocytes (open circle), hemoglobin ( $\mathrm{Hb}$; filled square), and platelets (open square) of the infant are shown. Corrected WBC, lymphocytes, and $\mathrm{Hb}$ were low at birth. Corrected WBC and lymphocytes increased after day 30. Anemia improved after day 80 . The decreased platelet count recovered at around day 20 . The infant was discharged on day 32 .

infection. The boy later developed thrombocytopenia (-Fig. 2). Breast-feeding was started at day 0 , and fortified milk was added at day 6 ; breast-feeding was stopped at day 16 due to maternal steroid pulse therapy. Neonatal 6TGN levels gradually decreased, which was well approximated to the exponential function: $y=1659 e^{-0.074 x}$, $R^{2}=0.972$ (-Fig. 3).

The baby gained weight properly and was discharged at day 32. At 4 months of age (corrected: 3 months old), physical

Table 1 Laboratory findings at birth

\begin{tabular}{|l|l|l|l|l|l|}
\hline WBC & $8100 / \mu \mathrm{L}$ & RBC & $2.23 \times 10^{6} / \mu \mathrm{L}$ & T-Bil & $2.6 \mathrm{mg} / \mathrm{dL}$ \\
\hline Stab & $0 \%$ & $\mathrm{Hb}$ & $10.6 \mathrm{~g} / \mathrm{dL}$ & D-Bil & $0.9 \mathrm{mg} / \mathrm{dL}$ \\
\hline Seg & $71 \%$ & $\mathrm{Hct}$ & $30.2 \%$ & AST & $24 \mathrm{IU} / \mathrm{L}$ \\
\hline Eosi & $0 \%$ & $\mathrm{MCV}$ & $135.4 \mathrm{fL}$ & ALT & $2 \mathrm{IU} / \mathrm{L}$ \\
\hline Baso & $0 \%$ & $\mathrm{MCH}$ & $47.5 \mathrm{pg}$ & $\mathrm{LDH}$ & $377 \mathrm{IU} / \mathrm{L}$ \\
\hline Mono & $13 \%$ & $\mathrm{MCHC}$ & $35.1 \mathrm{~g} / \mathrm{dL}$ & $\mathrm{TP}$ & $4.2 \mathrm{~g} / \mathrm{dL}$ \\
\hline Lymph & $8 \%$ & $\mathrm{Plt}$ & $293 \times 10^{3} / \mu \mathrm{L}$ & ALB & $2.8 \mathrm{~g} / \mathrm{dL}$ \\
\hline At-Ly & $5 \%$ & $\mathrm{PH}$ & 7.129 & $\mathrm{CK}$ & $220 \mathrm{IU} / \mathrm{L}$ \\
\hline Myelo & $0 \%$ & $\mathrm{PCO}$ & $49.3 \mathrm{~mm} \mathrm{Hg}$ & BUN & $23 \mathrm{mg} / \mathrm{dL}$ \\
\hline Meta & $1 \%$ & $\mathrm{BE}$ & $-12.9 \mathrm{mEq} / \mathrm{L}$ & $\mathrm{Cre}$ & $2.2 \mathrm{mg} / \mathrm{dL}$ \\
\hline Promyelo & $1 \%$ & $\mathrm{Na}$ & $132.6 \mathrm{mEq} / \mathrm{L}$ & $\mathrm{CRP}$ & $0.05 \mathrm{mg} / \mathrm{dL}$ \\
\hline Blast & $1 \%$ & $\mathrm{~K}$ & $4.24 \mathrm{mEq} / \mathrm{L}$ & $\mathrm{IgC}$ & $760 \mathrm{mg} / \mathrm{dL}$ \\
\hline Erb/100 WBC & 168 & $\mathrm{Cl}$ & $107 \mathrm{mEq} / \mathrm{l}$ & $\mathrm{IgA}$ & $<1 \mathrm{mg} / \mathrm{dL}$ \\
\hline Corrected WBC & $3022 / \mu \mathrm{L}$ & $\mathrm{iCa}$ & $1.41 \mathrm{mmol} / \mathrm{L}$ & $\mathrm{IgM}$ & $<1 \mathrm{mg} / \mathrm{dL}$ \\
\hline & & $\mathrm{Glu}$ & $93 \mathrm{mg} / \mathrm{dL}$ & & \\
\hline
\end{tabular}

Abbreviations: WBC, white blood cell; Stab, stab neutrophil; Seg, segmented neutrophil; Eosi, eosinophil; Baso, basophil; Mono, monocyte; Lymph, lymphocyte; At-Ly, atypical lymphocyte; Myelo, myelocyte; Promyelo, promyelocyte; Erb, erythroblast; RBC, red blood cell; Hb, hemoglobin; Hct, hematocrit; MCV, mean corpuscular volume; MCH, mean corpuscular hemoglobin; MCHC, mean corpuscular hemoglobin concentration; PIt, platelet; BE, base excess; iCa, ionized calcium; Glu, glucose; T-Bil, total bilirubin; D-Bil, direct bilirubin; AST, aspartate transaminase; ALT, alanine transaminase; LDH, lactate dehydrogenase; TP, total protein; ALB, albumin; CK, creatine kinase; BUN, blood urea nitrogen; Cre, creatinine; CRP, creactive protein; IgG, immunoglobulin $\mathrm{G}$; IgA, immunoglobulin A; IgM, immunoglobulin M. 


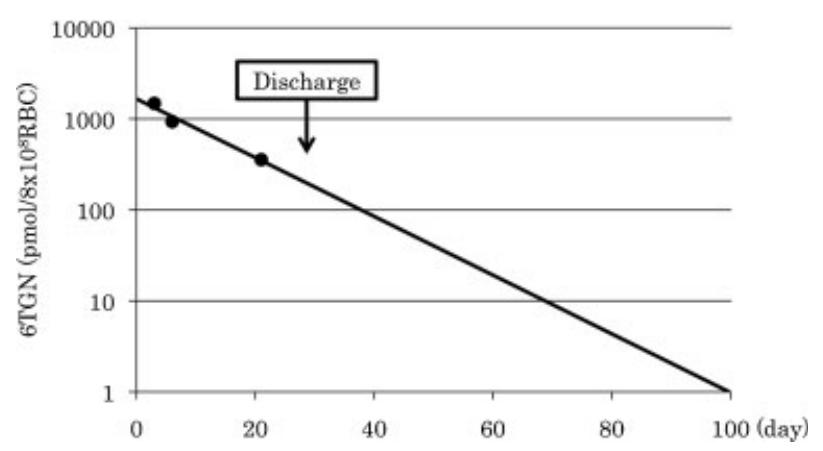

Fig. 3 The trend of neonatal 6-thioguanine nucleotides (6TGN) levels is shown. It was approximated to the exponential function: $y=1659 e^{-0.074 x}, R^{2}=0.972$. RBC, red blood cells.

and mental development were normal. The TPMT genotype of the mother was not determined.

\section{Discussion}

Maternal AZA dose at the time of delivery was $75 \mathrm{mg} / \mathrm{d}$ $(1.5 \mathrm{mg} / \mathrm{kg} / \mathrm{d})$, which is a normal dose used clinically. ${ }^{8}$ However, maternal 6TGN levels at day $2\left(1890 \mathrm{pmol} / 8 \times 10^{8} \mathrm{RBC}\right)$ were extremely high, which could have been attributed to TPMT polymorphism and/or maternal renal dysfunction. ${ }^{5-7,9}$ Despite the high 6TGN levels, the mother did not present with leukocytopenia or thrombocytopenia. Hanai et al reported that leukocytopenia was observed when 6TGN levels exceeded $320 \mathrm{pmol} / 8 \times 10^{8} \mathrm{RBC}$, with an incidence of approximately $20 \%{ }^{6}$ And Lennard et al showed that the patient had leukocytopenia when 6TGN level went over $300 \mathrm{pmol} /$ $8 \times 10^{8}$ RBC. $^{10}$ Thus, less than $300 \mathrm{pmol} / 8 \times 10^{8} \mathrm{RBC}$ would not be high. We did not check TPMT polymorphism or TPMT activity. There was an inverse relationship between 6TGN levels in RBC and TPMT enzyme activity in the patients who had 6 mercaptopurine, ${ }^{6}$ which was metabolized to 6 TGN. The range of 6TGN level in the blood was from 100 to $700 \mathrm{pmol} /$ $8 \times 10^{8}$ RBC. Thus, we could not easily estimate the 6TGN level. At day 3, when the infant did not have sufficient breast milk, neonatal 6TGN levels remained high, suggesting that these high levels were due to exposure through the placenta. As neonatal 6TGN levels declined, pancytopenia gradually improved.
In conclusion, there was no correlation between maternal AZA dose and maternal blood 6TGN levels. Furthermore, no distinct side effects were observed in the mother despite her high 6TGN levels. Taken together, our findings suggest that maternal blood 6TGN levels could be used to predict fetal pancytopenia.

\section{Acknowledgments}

We thank our colleagues Naoko Nakamura, Shigehiro Mori, Hirosuke Morita, Akihito Takeuchi, Eiko Toda, Yoko Yamabe, Kazue Nakamura, and Makoto Nakamura at the Okayama Medical Center.

\section{References}

1 DeWitte DB, Buick MK, Cyran SE, Maisels MJ. Neonatal pancytopenia and severe combined immunodeficiency associated with antenatal administration of azathioprine and prednisone. J Pediatr 1984;105:625-628

2 Armenti VT, Moritz MJ, Davison JM. Drug safety issues in pregnancy following transplantation and immunosuppression: effects and outcomes. Drug Saf 1998;19:219-232

3 Tidd DM, Paterson AR. A biochemical mechanism for the delayed cytotoxic reaction of 6-mercaptopurine. Cancer Res 1974;34: 738-746

4 Lennard L. The clinical pharmacology of 6-mercaptopurine. Eur J Clin Pharmacol 1992;43:329-339

5 Nguyen CM, Mendes MA, Ma JD. Thiopurine methyltransferase (TPMT) genotyping to predict myelosuppression risk. PLoS Curr 2011;3:RRN1236

6 Hanai H, Iida T, Takeuchi K, et al. Thiopurine maintenance therapy for ulcerative colitis: the clinical significance of monitoring 6-thioguanine nucleotide. Inflamm Bowel Dis 2010;16:1376-1381

7 Bergan S. Optimisation of azathioprine immunosuppression after organ transplantation by pharmacological measurements. BioDrugs 1997;8:446-456

8 Gardiner SJ, Gearry RB, Roberts RL, Zhang M, Barclay ML, Begg EJ. Exposure to thiopurine drugs through breast milk is low based on metabolite concentrations in mother-infant pairs. Br J Clin Pharmacol 2006;62:453-456

9 Schmiegelow K, Kriegbaum NJ. 6-Thioguanine nucleotide accumulation in erythrocytes during azathioprine treatment for systemic connective tissue diseases: a possible index for monitoring treatment. Ann Rheum Dis 1993;52:152-154

10 Lennard L, Harrington CI, Wood M, Maddocks JL. Metabolism of azathioprine to 6-thioguanine nucleotides in patients with pemphigus vulgaris. Br J Clin Pharmacol 1987;23:229-233 